\title{
Demir-Çelik Sektörü Çalışanlarının Örgütsel Bağlılık Düzeylerinin İncelenmesi: Kardemir Örneği (Organizational Commitment Levels of Iron and Steel Industry Employees: Kardemir Case)
}

\author{
Volkan TEMIZKAN iD a Kasım YILMAZ iD b \\ a Karabük Üniversitesi, Sosyal Bilimler Meslek Yüksekokulu, Karabük, Türkiye. vtemizkan@karabuk.edu.tr \\ ${ }^{\mathrm{b}}$ Karabük Üniversitesi, TOBB Teknik Bilimler Meslek Yüksekokulu, Karabük, Türkiye. kasimyilmaz@karabuk.edu.tr
}

\begin{tabular}{ll}
\hline MAKALE BİLGISI & ÖZET \\
\hline Anahtar Kelimeler: & Amaç - Bu araştırmanın temel amacı demir çelik sektörü çalışanlarının ünite ve fabrika bazında örgütsel \\
Örgütsel Bağlllık & $\begin{array}{l}\text { bağlılık nitelik ve seviyeleriyle çeşitli demografik özellikleri arasındaki ilişkileri belirlemek ve anlamaya } \\
\text { Demir Çelik Sektörü }\end{array}$
\end{tabular}

Duygusal Bağllilk

Devam Bağllil̆ğ1

Normatif Bağlllık

Yöntem - Bu çalışmada kesin sonuç araştırmalarından tanımlayıcı kesitsel araştırma türü kullanılmıştır. 2019 yılında İstanbul Sanayi Odası (İSO) tarafından Türkiye'nin 23'ncü en başarılı sanayi firması olarak ilan edilen Kardemir A.Ş.'nin toplamda 4.159 kişi olan çalışanları bu araştırmanın evrenini oluşturmaktadır. Fabrika' da düzenlenen hizmet içi eğitimine katılan çalışanlar ile kasti örnekleme yöntemiyle 250 kişiye yüz yüze anket uygulanmış ve 216 anket değerlendirmeye uygun görülmüştür. İşletmede değişik kademelerde

Gönderilme Tarihi 2 Şubat 2021

Revizyon Tarihi 9

Haziran 2021 çalışan personelin çalıştıkları ünite ve işletmeye yönelik örgütsel bağlllıklarının nitelik ve düzeyinin belirlenmesi için Allen ve Meyer (1990;18) tarafından geliştirilen “Örgütsel Bağlılık Ölçeği” kullanılmıştır. Çalışanların örgütsel bağlılı̆̆ının demografik özellikler ve birim türlerine göre farklılık gösterip göstermediği ' $t$ ' ve 'ANOVA' testleriyle, boyutlar arasındaki ilişkiler korelasyon analiziyle incelenmiştir.

Kabul Tarihi 15 Haziran 2021

Bulgular - Araştırma sonucunda, çalışanların demografik özelliklerinin bazılarıyla örgütsel bağlılık bileşenleri arasında anlamlı farklılıklar bulunmuştur. Çalışanların işletme geneline yönelik örgütsel bağlılıkları üniteye duyulan bağlılıklarından daha yüksek çıkmıştır. Ayrıca çalışanların duygusal bağlılık düzeylerinin diğer bileşenlere göre daha yüksek çıktığı görülmüştür.

Makale Kategorisi: Araştırma Makalesi

Tartışma - İşletmeler, çalışanlarının duygusal bağlılık düzeylerini daha da güçlendirmek için hem onların çalıştıkları birimleri daha çok sevip benimsemelerini sağlamalı, hem de işletme geneliyle ilgili kanaatlerini olumlu yönde geliştirmeye çalışmalıdırlar.

\begin{tabular}{l} 
ARTICLE INFO \\
\hline Keywords: \\
Organizational \\
Commitment \\
Iron and Steel Sector \\
Emotional Commitment \\
Continuity Commitment \\
Normative Commitment
\end{tabular}

Received 2 February 2021 Revised 9 June 2021 Accepted 15 June 2021

\section{ABSTRACT}

Purpose - The main purpose of this study is to determine and understand the relationships between iron and steel industry employees' unit and factory based organizational commitments and their demographic characteristics. In this research face-to-face surveys were conducted according to easy sampling method with Kardemir employees which was declared as Turkey's 23rd most successful industrial company by Istanbul Chamber of Industry (ISO) in 2019.

Design/methodology/approach - In this study, descriptive cross-sectional research type, which is one of the definitive results studies, was used. Kardemir A.Ş. was ranked as the 23rd among most successful first five hundred industrial company of Turkey by the Istanbul Chamber of Industry (ISO) in 2019. Kardemir A.Ş. employees, totally 4,159 people constitute the universe of this research. A face-to-face survey was applied to 250 people according to intentional sampling method with the employees participated in an inservice training held at the factory. 216 surveys were deemed appropriate for evaluation. The "Organizational Commitment Scale" developed by Allen and Meyer $(1990 ; 18)$ was used to determine the quality and level of organizational commitment of the personnel working at different levels in the company. The effects of demographic characteristics and unit types on organizational commitment levels of the employees were examined with ' $t$ ' and 'ANOVA' tests, and the relations between the dimensions were analyzed by correlation analysis.

Article Classification: Research Article

Findings - According to the results significant differences were found between some of the employees' demographic characteristics and organizational commitment components. Employees' factory based organizational commitment levels were found to be higher than their unit based commitment levels. In addition, emotional commitment level of the employees was found to be higher than other components.

Discussion - In order to further strengthen the emotional commitment level of their employees, businesses should support them to better like the units they work in, and also try to improve employees' opinion about overall company in a positive way.

\section{Önerilen Atıf/Suggested Citation}

Temizkan, V., Yılmaz, K. (2021). Demir-Çelik Sektörü Çalışanlarının Örgütsel Bağlılık Düzeylerinin İncelenmesi: Kardemir Örneği, İşletme Araştırmaları Dergisi, 13 (2), 1538-1552. 


\section{GIRISŞ}

Örgütsel bağlılık, çalışanın kurumsal amaç ve değerleri benimsemesi, bu amaçlara ulaşmak için çaba sarf etmesi ve kurum üyeliğini devam ettirme arzusudur. Örgütsel bağlllı̆̆ın türlerinden ziyade ayırt edilebilir unsurları olarak görülen üç farklı bağlılık bileşeni bulunmaktadır. Bu bileşenler duygusal (affective), devam (continuance) ve normatif (normative) bağlllıktır. Duygusal bağlllı̆ga sahip olan çalışan işletmede kalmak istediğini, devam bağlılığına sahip olan çalışan ise işletmede kalma mecburiyetinde olduğunu düşünür. Normatif bağlllı̆̆a sahip olan çalışan ise kişisel olarak doğru olan şeyin örgütte kalmak olduğuna inanır (Allen ve Meyer, 1990;3).

Yapılan araştırmalarda genelde örgütsel bağlllı̆̆ı yüksek olan çalışanların örgüt üyeliklerini devam ettirecekleri, çalıştıkları kurumun amaç ve değerlerini benimsedikleri, örgüt yararına daha fazla çaba harcayacakları ve örgütün başarısı yönünde daha yüksek bir performansla çalışacakları ortaya konulmaktadır (Fındık \& Eryeşil, 2012;1252). Bu sebepten dolayı işletmeler çalışanlarının hangi motivasyon unsurlarından etkilenerek, ne tür bir örgütsel bağlllık geliştirdiklerini irdelemek durumundadırlar. Bu araştırma 1937 yılında kurulan ve Türkiye'nin ilk 500 sanayi kuruluşu arasında yer alan Kardemir Karabük Demir Çelik Sanayi ve Ticaret A.Ş. çalışanlarının örgütsel bağlllık yönelimlerini incelemeyi hedeflemektedir (İSO, 2019;26).

Kardemir Karabük Demir Çelik Sanayi ve Ticaret A.Ş. kurulduğu ilk yıllarda nitelikli çalışan bulmakta büyük güçlükler yaşamıştır. Başlangıçta \%90 oranında İngilizlerin nezaretinde olan fabrika idaresi, ülkedeki çeşitli atölyelerden getirilen kalifiye ustaların da gayretleriyle Türk mühendis ve ustalarına devredilmiştir. Zamanla Türk işçileri de işe intibak etmişlerdir. Başlangıçta niteliği itibarıyla fabrikada dört grup işçi çalışmaktaydı ve bu gruplar içerisinde A dereceli işçiler en kalifiye ve zor yetiştirilen işçilerdi. Fabrika bu işçilerin niteliklerinin arttırılması, işin tekniğine ve zorluğuna alıştırılması için oldukça fazla gayret etmiştir (Çehreli, 1966;145).

1944 yılı verilerine göre, fabrikada işten ayrılanların oranı \%90’ları bulmuştur. Örgütsel bağlılığın arttırılması için daimi zamanlı işçi sayısı arttırılmıştır. Kalan işçi ihtiyacı kısmi zamanlı çalışanlarla çözülmeye çalışılmıştır. 1940'lı yıllarda sektörde önemli miktarda mahkum işçi de çalıştırılmıştır. Yüksek işçi devri sorunu başlangıçta kanuni düzenlemelerle engellenmeye çalışılmış, daha sonra sosyal, ekonomik ve kültürel imkanların geliştirilmesiyle aşılmaya çalışılmıştır. Bu çerçevede prim sistemi, sosyal konutlar, ücretsiz ulaşım gibi araçlar kullanılmıştır. Çalışanlar yurtiçi ve yurtdışında mesleki eğitim kurslarına gönderilerek sektörde kalıcı olmaları teşvik edilmiştir (Aydın, 2018;276). Gelişen teknoloji ve üretim yöntemleri ile birlikte demir çelik sektöründe iş tecrübesi ve uzmanlık giderek daha önemli hale gelmiştir. Bu nedenle sektörde kalifiye bir çalışanın işi bırakması yüksek maliyetler getirmektedir. Örgütsel bağlılık özellikle endüstriyel işletmelerde ihtiyaç duyulan nitelikli personeli örgüte çekme ve elde tutma açısından hayati öneme haiz bir konudur (Eslami ve Gharakhani, 2012;85).

Bu açıdan örgütsel bağlllı̆̆ın niteliği ve düzeyi demir çelik sektöründe diğer işkollarına oranla daha fazla bir öneme sahiptir. Çünkü bu sektörde işletmeler uzman personele her açıdan uzun vadeli olarak yatırım yapmak, onu elinde tutmak ve yüksek performans elde etmek zorundadır. Diğer bir deyişle demir çelik sektöründe yüksek işgücü devir hızı tehlikeli bir göstergedir.

Bu çalışma ile demir çelik sektöründeki bu tehlikenin nedeni çalışanların örgütlerine olan bağlılıklarında aranmıştır. Duyulan bu endişe örgütsel bağlllık ile ilgili olarak akıllara şu soruları getirmiştir: Çalışanların işyerlerine olan bağlılıkları çalıştığı birime veya işletme geneline göre neden farklılık göstermektedir? Kişi birimine karşı daha olumlu duygular besler iken işletme geneline karşı neden aynı duyguları beslememektedir? Ya da tam tersi işletmesi ile gurur duyarken çalıştı̆̆ birime karşı neden olumsuz bir tavır takınmaktadır? Bu soruların psikolojik, sosyolojik, ekonomik vb. açılardan birçok cevabı bulunmaktadır. Ancak bu çalışmada kişilerin örgütsel bağlllık düzeyleri arasındaki farklılık demografik özellikleri üzerinden aranmıştır.

Birim ve işletme düzeyinde örgütsel bağlllığı etkileyen unsurlar farklılık gösterebilmektedirler. Birim (ünite) düzeyinde çalışma ortamı, insan ilişkileri, iş tatmini, iş güçlüğü gibi unsurlar daha fazla etkiliyken işletme düzeyinde işletmenin marka değeri, çalışanına sağladığı maddi ve manevi faydalar daha fazla öne çıkmaktadır. Mesela örgütsel sinizm, birim düzeyinden daha ziyade işletme genelinden kaynaklanan bir kanaattir. Çalışanın işletmenin geneline ve yöneticilerine yönelik olarak geliştirdiği güvensizlik duygusuyla beslenir ve genel çerçevede örgütsel bağlllığı azaltıı bir etki doğurur (Yücel ve Çetinkaya, 2015;269). Bunun 


\section{Temizkan - K. Y1lmaz 13/2 (2021) 1538-1552}

tersi çalışanın işletmenin sağladığı sosyal ve ekonomik imkanlardan ve toplumdaki imajından çok memnun olmasına rağmen çalıştığı birimden kaynaklanan sebeplerle iş tatmini ve örgütsel bağlllık düzeyinin düşük olması durumudur.

İşletmenin bir biriminde faaliyet gösteren her bir çalışan bu birimdeki takımın bir parçasıdır. Takımın bir bütün olarak performansı ve başarısı örgütün başarısına katkı sağlamaktadır. Araştırmalar, takım olarak geliştirilen örgütsel bağlılı̆̆ın bireylerde daha fazla fedakarlık davranışına ve daha yüksek takım performansına yol açtı̆̆ını göstermektedir (Neininger vd., 2010;576). Kollektif örgütsel bağlllıkla, performans kalitesi ve hızı arasında anlamlı düzeyde ilişki olduğu belirlenmiştir. Kişisel olarak geliştirilen örgütsel tutumlar, aynı ünitede beraber çalışan kişiler arasındaki sosyalleşme sonucu daha kolay paylaşılmaktadır. Bu paylaşımla oluşan sinerji, örgütsel bağlllık düzeyi ve müşteri memnuniyeti arasında olumlu ilişkiler oluşturmaktadır (Conway ve Briner, 2012;483).

Çalışanların örgütsel düzeyde ve o örgütün bir biriminde yaptıkları iş düzeyinde sahip oldukları sosyalizasyonun boyutlarıyla örgütsel bağlılıkları, iş tatmini ve performansları ilişkili bulunmuştur (İplik, İplik \& Efeoğlu, 2012;111). Dolayısıyla hem birim düzeyinde hem de örgütsel düzeyde çalışanların örgütsel bağlılıklarının düzeyi ve niteliği ile aralarında bir ilişkinin olup olmadığının araştırılmasının faydalı olacağı değerlendirilmektedir.

Bu düşünceden hareketle araştırmamız temel olarak üç alanda değişkenler arasındaki ilişkiyi sorgulamak üzere dizayn edilmiştir. Birincisi örgütsel bağlılıkla çalışanların demografik özellikleri arasındaki ilişki, ikincisi çalışılan ünite ve işletme geneli düzeyinde çalışanların örgütsel bağlllıklarının farklılık gösterip göstermediği, üçüncüsü ise iş birimi ve örgütsel düzeyde örgütsel bağlllık bileşenlerinin niteliği ve birbirleri arasındaki ilişkidir. Bu çalışmada ünite veya işletme bazında çalışanların geliştirdikleri örgütsel bağlılık türü, düzeyi ve aralarındaki ilişkiler araştırılmaktadır.

Örgütsel bağlılık kavramının işletme genel düzeyi ve çalışılan birim şeklinde ikili düzeyde incelenerek bu değişkenler arasındaki ilişkinin sorgulanması bu araştırmanın özgün yönünü oluşturmaktadır.

\section{KAVRAMSAL ÇERÇEVE}

\section{1. Örgütsel Bă̆lılık}

Örgütsel bağlllık, bir kişinin örgütle özdeşleşmesi ve ona katılım derecesidir (Mowday vd., 2013;27). Özdeşleşme ve katılım, kişinin örgütün değer ve hedeflerini inanarak kabul etmesi, örgüt adına dikkate değer şekilde gayret gösterme istekliliğine sahip olması ve örgüt üyeliğini sürdürme konusunda güçlü bir niyete sahip olması sonuçlarını doğurur. Örgütsel bağlılık pasif bir sadakatten öte şahısların kendi rızalarıyla örgüte katkıda bulunma isteklilik ve çabalarıdır. Örgütsel bağlllı̆̆ı belirleyen faktörler; çalışanların kişisel özellikleri, işi ve işyerindeki rolünden kaynaklanan özellikler, örgütün yapısal özellikleri ve çalışanın iş tecrübesinden kaynaklanan unsurlardır. Örgütsel bağlllığın beklenen en önemli sonuçlarından biri düşük personel değişim oranıdır.

Örgütsel bağlılık çalışanların işyerleriyle ilgili tutum ve davranışlarını ve performanslarını etkiler (Tolentino, 2013;56). Davranışsal açıdan yaklaşım, örgütsel bağlılığın doğurduğu davranışlar ve bu davranışın sürdürülmesi biçiminde karakterize edilmiştir. Tutumsal açıdan örgütsel bağlllığın bileşenleri duygusal bağlılık, devamlılık bağlılığı ve normatif bağllılı olarak belirtilmektedir (Allen ve Meyer, 1990;3). Duygusal ve devamlılık bağlılığı işe giriş öncesi ve sonrası algılanan iş kalitesi ve alternatif iş imkanlarıyla ilişkili olarak gelişmektedir (Meyer, Bobocel \& Allen,1991;717). Duygusal bağlılık, çalışan ile örgüt arasındaki amaçların özdeşleşmesidir. Bu nedenle duygusal bağllık geliştiren çalışanlar örgütte kalmayı arzu ederler. Devamlılık bağlılığı kar-zarar ilişkisi gibi rasyonel düşünce odaklıdır. Bu nedenle işten ayrılma maliyetinin yüksek olduğu gören çalışan işte kalmanın daha avantajlı olacağı düşüncesiyle örgütte kalmaya devam etmek ister (Sayğan, 2011;221). Normatif bağlılık ise sadakat duygusuyla çalışanın örgütten ayrılmasının ahlaki bir davranış olmayacağı inancıyla oluşan bağlılık türünü ifade etmektedir (Allen ve Meyer, 1990;4).

Örgütsel bağlılı̆̆1 yüksek olan çalışanların verimliliği de yüksektir (Eaton, 2003;163). İşletmelerin örgütsel bağlılık uygulamaları çalışanlarının işten ayrılma niyetlerini azaltmaya veya ortadan kaldırmaya yöneliktir. Mesaiye zamanında gelmeme veya devamsızlık gibi olumsuz davranışların minimize edilmesi amaçlanır. Ayrıca, bu uygulamaların ürün ve hizmetlerin kalitesini olumlu yönde etkilediği anlaşılmıştır. 


\section{Temizkan - K. Yilmaz 13/2 (2021) 1538-1552}

\section{2. Örgütsel Bă̆hllı̆̆ı Etkileyen Faktörler ve Araştırma Hipotezleri}

Örgütsel bağlllığı belirleyen kişisel özellikler, rol ve iş özellikleri, yapısal özellikler ve iş deneyimleridir (Yalçın ve İplik, 2005;399). Tutumsal olarak örgütsel bağlılık nitelik ve düzeyine etki eden unsurlar hakkında çok sayıda çalışma yürütülmüştür. Bu araştırmalarda örgütsel bağlllık düzeyleriyle çalışanların demografik özellikleri arasındaki ilişkiler açısından değişik sonuçlar elde edilmiştir. Çolakoğlu vd. (2009;77)'nin yaptıkları çalışmaya göre otel çalışanlarında örgütsel bağlllık düzeyleri, katılımcıların demografik özelliklerine göre farklılık göstermektedir. Ancak başka bir araştırmada otel çalışanlarının normatif bağlılık düzeyleri demografik özelliklere göre farklılık göstermemekte ancak, duygusal ve devam bağlllı̆̆ düzeyleri bazı demografik özelliklere göre farklılık göstermektedir (Yalçın ve İplik, 2005;409).

Demografik özelliklerin dışında örgütsel bağlllık bileşenlerinin birçok farklı değişkenlerle ilişkisi de incelenmiştir. Yapılan araştırmalara göre yönetimin tarafsız ve adil olması ve işten duyulan tatmin, çalışanların duygusal bağlılığını arttırmaktadır (Powell ve Meyer, 2004;154) ; (Vandenberghe ve Peiro, 1999;577) ve (İplik vd., 2012;100). Örgütten ayrılmanın maliyeti çalışanların devam bağlılı̆̆ını arttırmaktadır (Powell ve Meyer, 2004;159). Demirçelik sektöründe birim ve işletme düzeyinde sosyalleşme, çalışanların örgütsel bağlılı̆̆ını, performansını ve iş tatmin seviyesini arttırmaktadır (İplik vd., 2012;112). Birim ve işletme düzeyinde örgütsel bağlllık türü ve düzeyinin belirlenmesi ve ikisi arasındaki ilişkilerin araştırılması bu araştırmanın hedefleri arasındadır. Çalışanın örgütsel bağlılığının arttırılabilmesi için onda gelişen örgütsel bağımlılı̆̆ın türü ve seviyesinin anlaşılması zorunludur.

Örgütsel bağlllık ile örgütsel sinizm arasında negatif bir ilişki bulunmakta (Yücel ve Çetinkaya, 2015;268), iş çevresinde maruz kalınan fiziki ve psikolojik şartlar da duygusal bağlılı̆̆ı etkilemektedir (Tolentino, 2013;54). Örgütlerdeki yöneticilik uygulamaları örgütsel bağlılığa etkide bulunmakta, işbirliğine dayalı liderlik ve eşit düzeyde destek uygulamaları duygusal bağlılığı, öğrenme işbirliği ise devamlılık bağlılığını arttırmaktadır (Joo, 2010;69).

İş performansı ve örgütsel vatandaşlık davranışıyla duygusal bağlılık arasında pozitif, devamlılık bağlılığıyla aynı davranışlar arasında negatif bir ilişki mevcuttur (Allen ve Grisaffe, 2001;223). İş kaybetme riskinin yüksek olduğu işletmelerde örgütsel bağlılık seviyesi azalmakta, piyasada işsizlik oranının yüksek olduğu durumlarda ise örgütsel bağlllık seviyesi artmaktadır (Furaker ve Berglund, 2014;183).

Örgütsel bağlılık çalışanların işten ayrılma niyetlerini etkileyen bir unsurdur. Dolayısıyla işletmeler çalışanlarının örgütsel bağlılık düzeylerini yüksek tutmak için çaba sarf etmelidirler. Örgütsel bağlılık sadece bireysel sezgilerden değil grup çalışmasının bireyleri etkilemesiyle de oluşur. Bu duruma kolektif örgütsel bağlılık denilmektedir. İşletmenin bir ünitesinde çalışanlar arasında paylaşımlar daha yoğun yaşandığından örgütsel bağlılık ünite seviyesinde daha kolay gerçekleşmekte ve performansı olumlu etkilemektedir (Conway ve Briner, 2012;472).

Araştırmalara göre ünite seviyesinde kollektif örgütsel bağlılıkla, performans kalitesi ve hızı arasında anlamlı düzeyde ilişki vardır (Conway ve Briner, 2012;480). Örgütsel bağlllık iş tatminini arttırmakta, işten ayrılma niyetini azaltmaktadır. Takım halinde örgütsel bağlılık daha yüksek takım performansı ve daha fazla fedakarlık davranışına yol açmaktadır (Neininger vd., 2010;573).

Kişisel olarak geliştirilen örgütsel tutumlar, aynı ünitede beraber çalışan kişiler arasındaki sosyalleşme sonucu daha kolay paylaşılmaktadır. Bu paylaşımla oluşan sinerji örgütsel bağlllıkla ve müşteri memnuniyeti arasında olumlu bir ilişkiye neden olur (Conway ve Briner, 2015;2051).

Yukarıda özetlenen araştırma sonuçları ve literatür dikkate alınarak aşağıdaki hipotezler oluşturulmuştur:

H1: Örgütsel bağlllık düzeyi işletme çalışanlarının demografik faktörlerine göre farklılık göstermektedir.

Araştırmada kullanılan demografik özellikler arasında cinsiyet, çalışılan pozisyon, çalışma süresi, eğitim durumu ve yaş dikkate alındığından $\mathrm{H}_{1}$ temel hipotezine bağlı olarak aşağıdaki alt hipotezler kurulmuştur.

H1.1: Örgütsel bağlllık düzeyi işletme çalışanlarının cinsiyetine göre anlamlı bir farklılık göstermektedir.

H1.2: Örgütsel bağlılık düzeyi işletme çalışanlarının pozisyonuna göre anlamlı bir farklılık göstermektedir.

H1.3: Örgütsel bağlılık düzeyi işletme çalışanlarının çalışma süresine göre anlamlı bir farklılık göstermektedir. 


\section{Temizkan - K. Y1lmaz 13/2 (2021) 1538-1552}

H1.4: Örgütsel bağlılık düzeyi işletme çalışanlarının eğitim durumuna göre anlamlı bir farklılık gösterir.

$H_{1.5:}$ Örgütsel bağlılık düzeyi işletme çalışanlarının yaşına göre anlamlı bir farklılık göstermektedir.

$\mathbf{H}_{2}$ : İşletme çalışanlarının örgütsel bağlılık düzeyleri çalıştıkları ünite ve fabrika geneli değişkenine göre anlamlı bir farklılık göstermektedir.

$\mathbf{H}_{3}$ : Fabrika ve ünite bazında örgütsel bağlllık bileşenleri arasında anlamlı bir ilişki vardır.

\section{YÖNTEM}

\subsection{Araştırmanın Türü}

Araştırma modelleri keşfedici ve kesin sonuç araştırmaları olmak üzere ikiye ayrılır. Kesin sonuç araştırmaları ise kendi içinde tanımlayıcı ve nedensel araştırmalar olmak üzere ikiye ayrılmaktadır (Malhotra, 2010: 102). Tanımlayıcı araştırmada amaç, araştırmanın amacına uygun değişkenleri ve değişkenler arasındaki ilgiyi tanımlamaktır (Yaşin, 2014: 51). Tanımlayıcı araştırmaların en belirgin özelliği araştırma öncesinde planlanmış bir sistematiğinin olmasıdır. Genellikle tüketiciler gibi belirli bir grubun yaş, eğitim seviyesi, işi gibi özelliklerini tanımlamaya yönelik araştırmalardır (Gegez, 2010: 38). Tanımlayıcı araştırma, kesitsel analizi türünde veya boylamsal analiz türünde yapılabilir. Kesitsel araştırmalar araştırılan olgu veya olguların belirli bir andaki durumunu ortaya koymak amacıyla yapılır. Birincil veri kullanan ve anket yönteminden faydalanan akademik çalışmalar genellikle bu yaklaşımı benimsemektedir çünkü sonuçlarının doğruluk derecesi ve karar almaya katkı yapma potansiyeli yüksektir (Mathur, 2008: 432). Bu doğrultuda çalışmada, problem tanımlandıktan ve hipotezler oluşturulduktan sonra tanımlayıcı araştırma türünün bir alt basamağı olan kesitsel araştırma kullanılmıştır.

\subsection{Evren ve Örneklem}

Kardemir A.Ş’nin tüm çalışanları (4.159 kişi) araştırmanın evrenini oluşturmakla birlikte zaman, maliyet ve emek kısıtları nedeni ile evrenin tümüne ulaşmanın mümkün olmamasından dolayı, 2019 yılında KARDEMİR A.Ş.' de düzenlenen "Afet ve Acil Durum Yönetimi" konulu hizmet içi eğitime alınan toplam 410 çalışan araştırmanın örneklem çerçevesini oluşturmaktadır. Eğitimler süresince kasti (yargısal) örnekleme yöntemiyle 250 çalışan ile yüz yüze anket uygulaması gerçekleştirilmiştir. Eğitimler sonunda toplanan 250 anketten 34 tanesi yanlış, isteksiz, eksik doldurma vb. nedenlerden dolayı analiz dışı bırakılmıştır. Geriye kalan 216 adet anket formu değerlendirmeye uygun görülmüştür. Örneklem büyüklüğünün belirlenmesinde farklı araştırmacılar tarafından farklı yöntemler benimsenmiştir. MacCallum ve arkadaşlarının (1999: 84-85) yaptığ1 bir literatür taramasında örnek büyüklügüün̈n oran kuralı temel alındığında ölçekteki ifade sayısının en az 10 katı olması gerektiğini belirtilmiştir. 17 Likert tipi ifadenin kullanıldığı bu araştırmada oran kuralına göre toplam ifade sayısının karşılaması gereken örneklem hacmi 170 olmalıdır. Bu kurala göre örneklem hacminin yeterli olduğu yargısına ulaşılmıştır.

\subsection{Veri Toplama Aract}

Veri toplama aracı olarak anket tercih edilmiştir. İki bölümden oluşan anketin ilk kısmında katılımcının demografik bilgilerini elde etmek üzere hazırlanan sorulara yer verilmiştir. İkinci kısmında ise Meyer ve Allen (1991) tarafından literatüre kazandırılan ve Boylu, Pelit ve Güçer (2007) tarafından Türkçe'ye uyarlanan “Örgütsel Bağlılık Ölçeği” kullanılmıştır. Ölçeğin ilk 6 ifadesi duygusal bağlılı̆̆ı, sonraki 6 ifadesi devamlılık bağlılığını, son 5 ifadesi ise normatif bağllı̆̆ğı ölçmeye yöneliktir ve toplam 17 ifadeden oluşmaktadır. Araştırmanın uygulama aşamasında katılımcılardan; örgütsel bağllılıla ilgili düşüncelerini belirtirken aktif olarak görev yaptıkları üniteyi ve işletmenin genelini ayrı ayrı değerlendirmeleri istenmiştir. Örgütsel bağlılık ölçeğinde (1) Kesinlikle Katılmıyorum (5) Kesinlikle Katılıyorum şeklindeki yanıtlardan oluşan 5'li Likert ölçeği kullanılmıştır. Literatürde birçok çalışmada (Dağlı vd.,2018:1773; Bağcı, 2013: 172) bu ölçeğin geçerlilik ve güvenlik çalışmalarının yapıldığı görülmüştür. Ancak bu çalışmada tekrar geçerlilik ve güvenilirlik analizleri yapılarak elde edilen sonuçlar Tablo 2'de gösterilmiştir.

\subsection{Verilerin Analizi}

216 adet anket formunun değerlendirilmesinde "SPSS 22" istatistik programı kullanılmıştır. Verilerin SPSS programına girilmesi sonrası 1 katılımcının anket formunda kayıp veriler olduğu görülmüştür. Kayıp veriler olması durumunda kullanılabilecek ilk akla gelen yöntemler dizin silme ve basit veri atama yöntemleridir. Bir 


\section{Temizkan - K. Y1lmaz 13/2 (2021) 1538-1552}

satırda az sayıda verinin eksik olması nedeniyle satır silme yerine basit veri atama yöntemlerinden ortalama atama ile kayıp verilerin tamamlanması analiz yazılımının özelliği ile yapılmıştır (Graham vd., 2012). Ölçekte yer alan boyutlara yönelik faktör analizi uygulanmıştır. Araştırma kapsamında geliştirilen hipotezleri test etmek için ise t-testi, ANOVA testi ve korelasyon analizi kullanılmıştır. Analizler sonucu elde edilen bulgular aşağıda yer almaktadır.

\section{BULGULAR}

Aşağıda, Tablo 1'de katılımcıların demografik özellikleri yer almaktadır.

Tablo 1. Katılımcıların Demografik Özellikleri

\begin{tabular}{|c|c|c|c|c|c|c|c|}
\hline & Değişken & $f$ & $\%$ & & Değişken & $f$ & $\%$ \\
\hline \multirow[t]{2}{*}{ Cinsiyet } & Kadın & 12 & 5,6 & \multirow[t]{2}{*}{ Medeni Durum } & Evli & 186 & 86,1 \\
\hline & Erkek & 204 & 94,4 & & Bekâr & 30 & 13,9 \\
\hline \multirow{4}{*}{ Yaş } & $21-30$ & 34 & 15,7 & \multirow{6}{*}{ Pozisyon } & Yönetici & 5 & 2,3 \\
\hline & $31-40$ & 87 & 40,3 & & Mühendis & 9 & 4,2 \\
\hline & $41-50$ & 93 & 43,1 & & Teknik Personel & 6 & 2,8 \\
\hline & $51-60$ & 2 & ,9 & & Üretim Operatörü & 5 & 2,3 \\
\hline \multirow{8}{*}{$\begin{array}{l}\text { Eğitim } \\
\text { durumu }\end{array}$} & İlkokul & 4 & 1,9 & & Diğer & 23 & 10,6 \\
\hline & Ortaokul & 12 & 5,6 & & İşçi & 168 & 77,8 \\
\hline & Lise & 142 & 65,7 & \multirow{6}{*}{$\begin{array}{l}\text { Kurumda çalışma } \\
\text { süresi }\end{array}$} & 5 yil ve daha az & 29 & 13,4 \\
\hline & Yüksekokul & 33 & 15,3 & & 6-10 yıl & 87 & 40,3 \\
\hline & Üniversite & 24 & 11,1 & & $11-15$ y1l & 3 & 1,4 \\
\hline & Yüksek lisans & 1 &, 5 & & $16-20$ yil & 40 & 18,5 \\
\hline & & & & & 20 yll ve üzeri & 57 & 26,4 \\
\hline & Toplam & 216 & 100 & & Toplam & 216 & 100 \\
\hline
\end{tabular}

Tablo 1'e göre, araştırmaya katılanların \%94,4 gibi bir çoğunluğunu erkekler oluşturmaktadır. Araştırmada yer alan bireylerin \%86,1'i evli ve eğitim durumları itibariyle \%65,7'si lise mezunudur. Çalışmada yer alan bireyler çalışma pozisyonuna göre değerlendirildiğinde; $\% 77,8$ ' $\mathrm{i}$ işçi düzeyinde, $\% 10,6$ 's diğer pozisyonlarda ve \%4,2'si ise mühendis düzeyinde çalışmaktadır. Çalışanların çoğunluğu 31-50 (\%83,4) yaş aralığında yer almaktadır. Ayrıca katılımcıların \%40,3'ü 6-10 yıl arası çalışma süresine sahiptir. Aşağıda Tablo 2'de örgütsel bağlllık ölçeğine ilişkin faktör analizi, güvenilirlik analizi, ortalama ve standart sapma değerleri verilmiştir.

Tablo 2. Faktör Analizi ve Değişkenlere Ait Tanımlayıcı İstatistikler

\begin{tabular}{|c|c|c|c|c|c|c|c|}
\hline Boyut & İfade & & $\begin{array}{l}\text { Fakt. } \\
\text { Yükü }\end{array}$ & Cr. Alpha & s.s. & $\bar{x}$ & $\bar{X}$ \\
\hline \multirow{12}{*}{ 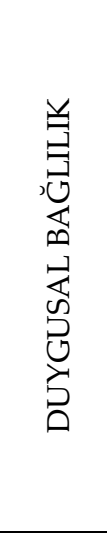 } & \multirow{2}{*}{$\begin{array}{l}\text { Bundan sonraki kariyerimi bu işletmede } \\
\text { tamamlamaktan mutluluk duyarım. }\end{array}$} & $\mathbf{F}$ & ,792 & \multirow{6}{*}{$\begin{array}{l}\text { Fabrika } \\
\alpha=92 \\
(\mathrm{KMO}=, 884 \\
\text { Açıklanan } \\
\text { varyans=86,7) }\end{array}$} & ,98 & 4,1 & \multirow{12}{*}{$\begin{array}{l}F=4,08 \\
\ddot{U}=4,01\end{array}$} \\
\hline & & $\ddot{\mathrm{U}}$ & ,804 & & 1,16 & 3,8 & \\
\hline & \multirow{2}{*}{$\begin{array}{l}\text { Çalıştığım işletmenin sorunlarını } \\
\text { sorunlarım gibi hissederim. }\end{array}$} & $\mathbf{F}$ & ,702 & & ,94 & 4,1 & \\
\hline & & $\ddot{\mathrm{U}}$ & ,277 & & 2,25 & 4,2 & \\
\hline & \multirow{2}{*}{$\begin{array}{l}\text { Çalıştığım olduğum bu işletmede kendimi bu } \\
\text { ailenin bir parçası gibi hissederim. }\end{array}$} & $\mathbf{F}$ & ,895 & & 1,15 & 3,9 & \\
\hline & & $\ddot{\mathrm{U}}$ & 887 & & 1,21 & 3,8 & \\
\hline & \multirow{2}{*}{$\begin{array}{l}\text { Çalışmış olduğum bu işletmeyle aramda } \\
\text { duygusal bir bağ hissediyorum. }\end{array}$} & $\mathbf{F}$ & 834 & \multirow{6}{*}{$\begin{array}{l}\text { Ünite } \\
\alpha=, 80 \\
(\mathrm{KMO}=, 884 \\
\text { Açıllanan } \\
\text { varyans }=85,2)\end{array}$} & 1,05 & 4,0 & \\
\hline & & $\ddot{\mathrm{U}}$ & 869 & & 1,08 & 3,9 & \\
\hline & \multirow{2}{*}{$\begin{array}{l}\text { Çalışmış olduğum bu işletmeye karşı güçlü bir } \\
\text { aidiyet duyuyorum. }\end{array}$} & $\mathbf{F}$ & ,794 & & ,99 & 4,0 & \\
\hline & & $\ddot{U}$ & ,780 & & 1,06 & 4,0 & \\
\hline & \multirow{2}{*}{$\begin{array}{l}\text { Çalışmış olduğum bu işletmeden çevreme } \\
\text { gururla bahsederim. }\end{array}$} & $\mathbf{F}$ & ,809 & & ,96 & 4,1 & \\
\hline & & $\ddot{U}$ & 708 & & ,99 & 4,1 & \\
\hline \multirow{6}{*}{ 当五 } & \multirow{2}{*}{$\begin{array}{l}\text { Bugün bu işletmeden ayrılmam ileriki hayatımda } \\
\text { maddi kayıplar yaşamama neden olur. }\end{array}$} & $\mathbf{F}$ & ,675 & \multirow{6}{*}{$\begin{array}{l}\text { Fabrika } \\
\alpha=, 86 \\
(\mathrm{KMO}=, 864 \\
\text { Açıllanan } \\
\text { varyans=79,2) }\end{array}$} & 1,09 & 3,9 & \multirow{6}{*}{$\begin{array}{l}F=3,63 \\
\ddot{U}=3,56\end{array}$} \\
\hline & & $\ddot{U}$ & ,662 & & 1,18 & 3,7 & \\
\hline & \multirow{2}{*}{$\begin{array}{l}\text { Bugün bu işletmeye devam ediyor olmam } \\
\text { istekten daha çok gerekliliktir. }\end{array}$} & $\mathbf{F}$ & ,792 & & 1,25 & 3,4 & \\
\hline & & $\ddot{U}$ & ,769 & & 1,21 & 3,4 & \\
\hline & \multirow{2}{*}{$\begin{array}{l}\text { Bu işletmeden ayrılma fikri karşısında çok az } \\
\text { seçeneğim olduğuna inanıyorum. }\end{array}$} & $\mathbf{F}$ & 827 & & 1,25 & 3,4 & \\
\hline & & $\ddot{\mathbf{U}}$ & 827 & & 1,20 & 3,4 & \\
\hline
\end{tabular}


V. Temizkan - K. Y1lmaz 13/2 (2021) 1538-1552

\begin{tabular}{|c|c|c|c|c|c|c|c|}
\hline & $\mathrm{Bu}$ işletmeden ayrılmış olmanın yol açacağı & $\mathbf{F}$ & 673 & \multirow{6}{*}{$\begin{array}{l}\text { Ünite } \\
\alpha=, 84 \\
(\mathrm{KMO}=, 858 \\
\text { Açıklanan } \\
\text { varyans=77,9) }\end{array}$} & 1,12 & 3,6 & \\
\hline & $\begin{array}{l}\text { olumsuz sonuçlardan biri de, başka bir } \\
\text { işletmenin bana bu imkan ve olanakları } \\
\text { sunamayacağı ihtimalidir. }\end{array}$ & $\ddot{\mathrm{U}}$ & ,655 & & 1,18 & 3,5 & \\
\hline & \multirow{2}{*}{$\begin{array}{l}\text { Yeni bir iş bulmadan bu işletmeden ayrıldığımda } \\
\text { neler olacağı konusunda kaygılıyım. }\end{array}$} & $\mathbf{F}$ & ,799 & & 1,21 & 3,6 & \\
\hline & & $\ddot{\mathrm{U}}$ & ,774 & & 1,20 & 3,6 & \\
\hline & \multirow{2}{*}{$\begin{array}{l}\text { Bu işletmede çalışmaya devam ediyor olmamın } \\
\text { en önemli sebeplerinden biri de ayrılmamın } \\
\text { kişisel özveri gerektirmesidir. }\end{array}$} & $\mathbf{F}$ & 612 & & 1,07 & 3,5 & \\
\hline & & $\ddot{\mathrm{U}}$ &, 595 & & 1,08 & 3,4 & \\
\hline \multirow{10}{*}{ 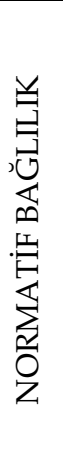 } & \multirow{2}{*}{$\begin{array}{l}\text { Avantajıma olduğunu bilsem bile çalıştı̆̆ım bu } \\
\text { işletmeden şu an ayrılmayı doğru bulmuyorum. }\end{array}$} & $\mathbf{F}$ & ,708 & \multirow{5}{*}{$\begin{array}{l}\text { Fabrika } \\
\alpha=, 86 \\
(\mathrm{KMO}=, 862 \\
\text { Açıllanan } \\
\text { varyans=85,2) }\end{array}$} & ,95 & 4,0 & \multirow{10}{*}{$\begin{array}{l}F=3,94 \\
\ddot{U}=3,83\end{array}$} \\
\hline & & $\ddot{\mathrm{U}}$ & ,590 & & 1,01 & 3,9 & \\
\hline & \multirow{2}{*}{ Bu işletme bağlılığımı ve sadakatimi hak ediyor. } & $\mathbf{F}$ & ,622 & & 1,00 & 4,0 & \\
\hline & & $\ddot{\mathrm{U}}$ & 661 & & 1,04 & 3,9 & \\
\hline & \multirow{2}{*}{$\begin{array}{l}\text { Bu işletmeden ayrılmamın mesai arkadaşlarıma } \\
\text { karşı duyduğum mesuliyetlerden dolayı yanlış } \\
\text { olacağı kanaatindeyim. }\end{array}$} & $\mathbf{F}$ & ,708 & & 1,09 & 3,7 & \\
\hline & & $\ddot{U}$ & 719 & \multirow{5}{*}{$\begin{array}{l}\text { Ünite } \\
\alpha=, 86 \\
(\mathrm{KMO}=, 862 \\
\text { Açıllanan } \\
\text { varyans=84,8) }\end{array}$} & 1,09 & 3,6 & \\
\hline & \multirow{2}{*}{$\begin{array}{l}\text { Çalıştığım bu işletmeye karşı çok şey borçlu } \\
\text { olduğumu düşünüyorum. }\end{array}$} & $\mathbf{F}$ & ,493 & & ,97 & 4,1 & \\
\hline & & $\ddot{\mathrm{U}}$ & ,588 & & 1,04 & 4,0 & \\
\hline & \multirow{2}{*}{$\begin{array}{l}\text { Bu işletmeden şu an ayrılırsam suçluluk } \\
\text { duyarım. }\end{array}$} & $F$ & 691 & & 1,28 & 3,6 & \\
\hline & & $\ddot{\mathrm{U}}$ & ,738 & & 1,28 & 3,5 & \\
\hline
\end{tabular}

Fabrika bazında güvenilirlik katsayısı $\alpha=0,91$; Ünite bazında güvenilirlik katsayısı $\alpha=0,88$

Fabrika=KMO örneklem yeterlilik ölçütü: \% 91,6; Barlett Küresellik testi: 2250,371; sd:136; p:0,00

Ünite= KMO örneklem yeterlilik ölçütü: \% 90,9; Barlett Küresellik testi: 1983,571; sd:136; p:0,00

Kullanılan ölçeğin içsel tutarlılığını belirlemek için Cronbach Alpha değeri hesaplanmıştır. Bu değer 0,80-1 arasında yüksek güvenilirliği ifade etmektedir (Tavakol and Dennick, 2011;54). Buradan hareketle ölçeğin geneline ait güvenilirlik katsayıları yüksek derecede güvenilir bir ölçek kullanıldığını göstermektedir. Ayrıca ölçeğin geçerliliğinin test edilebilmesi için faktör analizi uygulanmıştır. Ölçeğin faktör analizine uygunluğunu belirlemek için ise Kaiser-Meyer-Olkin (KMO) ve Bartlett"s Test of Sphericity (Bartlett Küresellik Testi) testleri uygulanmıştır. KMO değerlerinin 0,80'den büyük olması ve Bartlett küresellik testinin de anlamlı $(0,00<0,01)$ çıkmasıyla veri setinin faktör analizi için uygun olduğu görülmüştür. Örgütsel bağlllık ölçeğine ait üç faktör, fabrika bazında varyansın \% 66,8' ini açılarken ünite bazında \%63'ünü açıklamaktadır.

Çalışanların üniteye ve fabrikanın geneline yönelik üç bağlılık bileşeni ile ilgili en yüksek düzeyde katılım gösterdikleri ifadelerin sırasıyla duygusal, normatif ve devamlılık bağlılığı olduğu görülmektedir. Bağlllık türlerinin ünite ve fabrika bazında ortalamaları incelendiğinde; fabrikaya yönelik bağlılık ortalamalarının tamamının, üniteye yönelik olanlardan daha yüksek olduğu görülmektedir (Tablo 2).

Bilindiği gibi, t-testi, varyans analizi vb. karşılaştırmalı testlerde verilerin normal dağılımı ön koşullardan biridir. Çarpıklık katsayısının "0" olması ortalamaya göre tam simetrik dağılımı gösterir. Dağılımın normal olduğu çarpıklık (Skewness) ve basıklık (Kurtosis) katsayılarının $-1,5$ ile $+1,5$ arasında olması ile ortaya konulabilmektedir (Tabachnick, Fidell, 2013). Fabrika ve Ünite bazında değişkenlerde çarpıklığın -1,333 ile ,437 aralığında, basıklığın ise -1,479 ile ,491 aralığında değerler aldığı görülmüştür.

Ünite ve fabrika geneli bazında örgütsel bağlllık düzeylerinin çalışanların demografik özelliklerine göre farklılaşıp farklılaşmadığına ilişkin yapılan test sonuçları aşağıda Tablo 3, Tablo 4, Tablo 5, Tablo 6 ve Tablo 7 'de verilmiştir. 


\section{Temizkan - K. Y1lmaz 13/2 (2021) 1538-1552}

Tablo 3. Cinsiyet Değişkenine Göre Örgütsel Bağlılık Boyutlarının Farklılaşması (t-Testi)

\begin{tabular}{|c|c|c|c|c|c|c|c|}
\hline & & Cinsiyet & $\mathbf{n}$ & Ort. & s.s. & $\mathbf{t}$ & $\mathrm{p}$ \\
\hline \multirow[t]{6}{*}{ Fabrika } & Duygusal & Kadın & 12 & 4,45 & 64 & 1,540 & , 125 \\
\hline & Bağlılık & Erkek & 204 & 4,06 & 87 & & \\
\hline & Devamlılık & Kadın & 12 & 3,56 & 81 &,- 255 & 799 \\
\hline & Bağ $\operatorname{lil}_{1} \breve{g}_{1}$ & Erkek & 204 & 3,63 & 90 & & \\
\hline & Normatif & Kadın & 12 & 4,28 & ,78 & 1,411 & 160 \\
\hline & Bağlılık & Erkek & 204 & 3,92 & 85 & & \\
\hline \multirow[t]{6}{*}{ Ünite } & Duygusal & Kadın & 12 & 4,38 & 67 & 1,406 & 161 \\
\hline & Bağlılık & Erkek & 204 & 3,98 & ,97 & & \\
\hline & Devamlılık & Kadın & 12 & 3,59 & ,78 & 130 & 897 \\
\hline & Bağl11ı̆ğ & Erkek & 204 & 3,56 & 89 & & \\
\hline & Normatif & Kadın & 12 & 4,26 & 80 & 1771 & ,078 \\
\hline & Bağlılık & Erkek & 204 & 3,80 & 87 & & \\
\hline
\end{tabular}

Analiz sonuçlarına göre çalışanların hem ünite hem de fabrika bazında örgütsel bağlılık düzeyleri cinsiyet değişkenine göre istatistiksel olarak anlamlı $(\mathrm{p}>0,05)$ bir farklılık göstermemektedir. Bu sonuca göre $\mathrm{H}_{1.1}$ hipotezi reddedilmiştir.

Tablo 4. Medeni Durum Değişkenine Göre Örgütsel Bağlılık Boyutlarının Farklılaşması (t-Testi)

\begin{tabular}{|c|c|c|c|c|c|c|c|}
\hline & Boyutlar & $\begin{array}{l}\text { Medeni } \\
\text { Durum }\end{array}$ & $\mathbf{n}$ & Ort. & s.s. & $\mathbf{t}$ & $\mathbf{p}$ \\
\hline \multirow{6}{*}{ Fabrika } & Duygusal & Evli & 186 & 4,10 & 86 & \multirow{2}{*}{,- 887} & \multirow{2}{*}{,376 } \\
\hline & Bağlılık & Bekar & 30 & 3,95 & 89 & & \\
\hline & Devamlılık & Evli & 186 & 3,68 & 84 & \multirow{2}{*}{$-1,993$} & \multirow{2}{*}{,115 } \\
\hline & Bağl1lı̆̆ & Bekar & 30 & 3,33 & 1,13 & & \\
\hline & Normatif & Evli & 186 & 3,99 & 82 & \multirow{2}{*}{$-2,064$} & \multirow{2}{*}{ 040 } \\
\hline & Bağlılık & Bekar & 30 & 3,64 & ,98 & & \\
\hline \multirow{6}{*}{ Ünite } & Duygusal & Evli & 186 & 4,02 & ,96 & \multirow{2}{*}{,- 708} & \multirow{2}{*}{480} \\
\hline & Bağlılık & Bekar & 30 & 3,89 & ,92 & & \\
\hline & Devamlılık & Evli & 186 & 3,60 & 84 & \multirow{2}{*}{$-1,295$} & \multirow{2}{*}{ 204 } \\
\hline & Bağglılı̆ğ & Bekar & 30 & 3,33 & 1,08 & & \\
\hline & Normatif & Evli & 186 & 3,86 & 87 & \multirow{2}{*}{$-1,521$} & \multirow{2}{*}{ 130 } \\
\hline & Bağlılık & Bekar & 30 & 3,60 & ,91 & & \\
\hline
\end{tabular}

Ünite bazında bağlllık düzeylerinde medeni durum değişkenine göre anlamlı $(p>0,05)$ bir farklılık bulunamamıştır. Ancak, fabrika bazında sadece normatif bağlllık düzeyinin anlamlı $(p<0,05)$ bir farklılık gösterdiği görülmüştür. Bu sonuca rağmen diğer bileşenlerde anlamlı bir farklılık bulunamadığından $\mathrm{H}_{1.2}$ reddedilmiştir.

Tablo 5. Pozisyon Değişkenine Göre Örgütsel Bağlılık Boyutlarının Farklılaşması (ANOVA Testi)

\begin{tabular}{|c|c|c|c|c|c|c|c|}
\hline & Boyutlar & Pozisyon & $\bar{n}$ & Ort. & s.s. & $F$ & $\bar{p}$ \\
\hline \multirow{13}{*}{ 吕 } & \multirow[t]{6}{*}{ Duygusal Bağl. } & Yönetici & 5 & 4,56 &, 52 & \multirow{6}{*}{,70 } & \multirow{6}{*}{ 621 } \\
\hline & & Mühendis & 9 & 4,37 & 49 & & \\
\hline & & Teknik Personel & 6 & 3,97 & 43 & & \\
\hline & & Üretim Operatörü & 5 & 4,30 & ,32 & & \\
\hline & & Diğer & 23 & 4,16 & 83 & & \\
\hline & & İşçi & 168 & 4,04 & ,91 & & \\
\hline & \multirow[t]{6}{*}{ Devamlılık Bağl. } & Yönetici & 5 & 2,60 & 1,11 & \multirow{6}{*}{4,28} & \multirow{6}{*}{,001 } \\
\hline & & Mühendis & 9 & 2,66 & ,90 & & \\
\hline & & Teknik Personel & 6 & 3,66 & 86 & & \\
\hline & & Üretim Operatörü & 5 & 3,73 & ,59 & & \\
\hline & & Diğer & 23 & 3,48 & 1,03 & & \\
\hline & & İşçi & 168 & 3,73 &, 83 & & \\
\hline & Normatif Bağl. & Yönetici & 5 & 3,80 & 20 & ,23 & 946 \\
\hline
\end{tabular}


V. Temizkan - K. Yilmaz 13/2 (2021) 1538-1552

\begin{tabular}{|c|c|c|c|c|c|c|c|}
\hline & & Mühendis & 9 & 3,68 & 69 & & \\
\hline & & Teknik Personel & 6 & 4,00 &, 579 & & \\
\hline & & Üretim Operatörü & 5 & 4,00 & ,73 & & \\
\hline & & Diğer & 23 & 3,88 & 1,00 & & \\
\hline & & $\overline{\text { İşçi }}$ & 168 & 3,96 & 87 & & \\
\hline \multirow{18}{*}{ 䛼 } & Duygusal Bağl. & Yönetici & 5 & 4,56 & ,59 & \multirow{6}{*}{ 69 } & \multirow{6}{*}{,627 } \\
\hline & & Mühendis & 9 & 4,33 & 49 & & \\
\hline & & Teknik Personel & 6 & 3,94 &, 56 & & \\
\hline & & Üretim Operatörü & 5 & 4,30 & 32 & & \\
\hline & & Diğer & 23 & 4,02 & ,94 & & \\
\hline & & İşçi & 168 & 3,96 & 1,01 & & \\
\hline & Devamlılık Bağl. & Yönetici & 5 & 2,60 & 1,11 & \multirow{6}{*}{3,70} & \multirow{6}{*}{,003 } \\
\hline & & Mühendis & 9 & 2,66 & ,90 & & \\
\hline & & Teknik Personel & 6 & 3,55 & 84 & & \\
\hline & & Üretim Operatörü & 5 & 3,76 & ,57 & & \\
\hline & & Diğer & 23 & 3,45 & 94 & & \\
\hline & & İşçi & 168 & 3,65 & 84 & & \\
\hline & \multirow[t]{6}{*}{ Normatif Bağl. } & Yönetici & 5 & 3,80 & 20 & \multirow{6}{*}{,20 } & \multirow{6}{*}{,960 } \\
\hline & & Mühendis & 9 & 3,68 & 69 & & \\
\hline & & Teknik Personel & 6 & 4,00 &, 50 & & \\
\hline & & Üretim Operatörü & 5 & 4,00 & ,73 & & \\
\hline & & Diğer & 23 & 3,72 & 1,07 & & \\
\hline & & İडsçi & 168 & 3,84 & ,88 & & \\
\hline
\end{tabular}

Analiz sonuçlarına göre sadece devamlılık bileşeninde, hem ünite $(p=0,03<0,05)$ hem de fabrika $(p=0,01<0,05)$ bazında çalışanların bağlılığı, pozisyon değişkenine göre anlamlı bir farklılık göstermektedir. Bu sonuca rağmen diğer bileşenlerde anlamlı bir farklılık bulunamadığından $\mathrm{H}_{1.3}$ reddedilmiştir. Üniteye ve fabrikaya yönelik devamlılık bağlllığında gruplar arasında bir farklılık olduğuna göre tam bu noktada hangi gruplar arasında bir farklılığın olduğunu tespit etmek için Tukey testinden faydalanılmıştır. Tukey testi sonuçlarına göre işçilerin fabrikaya yönelik devamlılık bağllı̆̆ı, yönetici ve mühendislere göre daha fazladır. Yine işçilerin üniteye yönelik devamlılık bağlllıklarının mühendislere göre daha fazla olduğu görülmüştür.

Tablo 6. Çalışma Süresi Değişkenine Göre Örgütsel Bağlılık Boyutlarının Farklılaşması (ANOVA Testi)

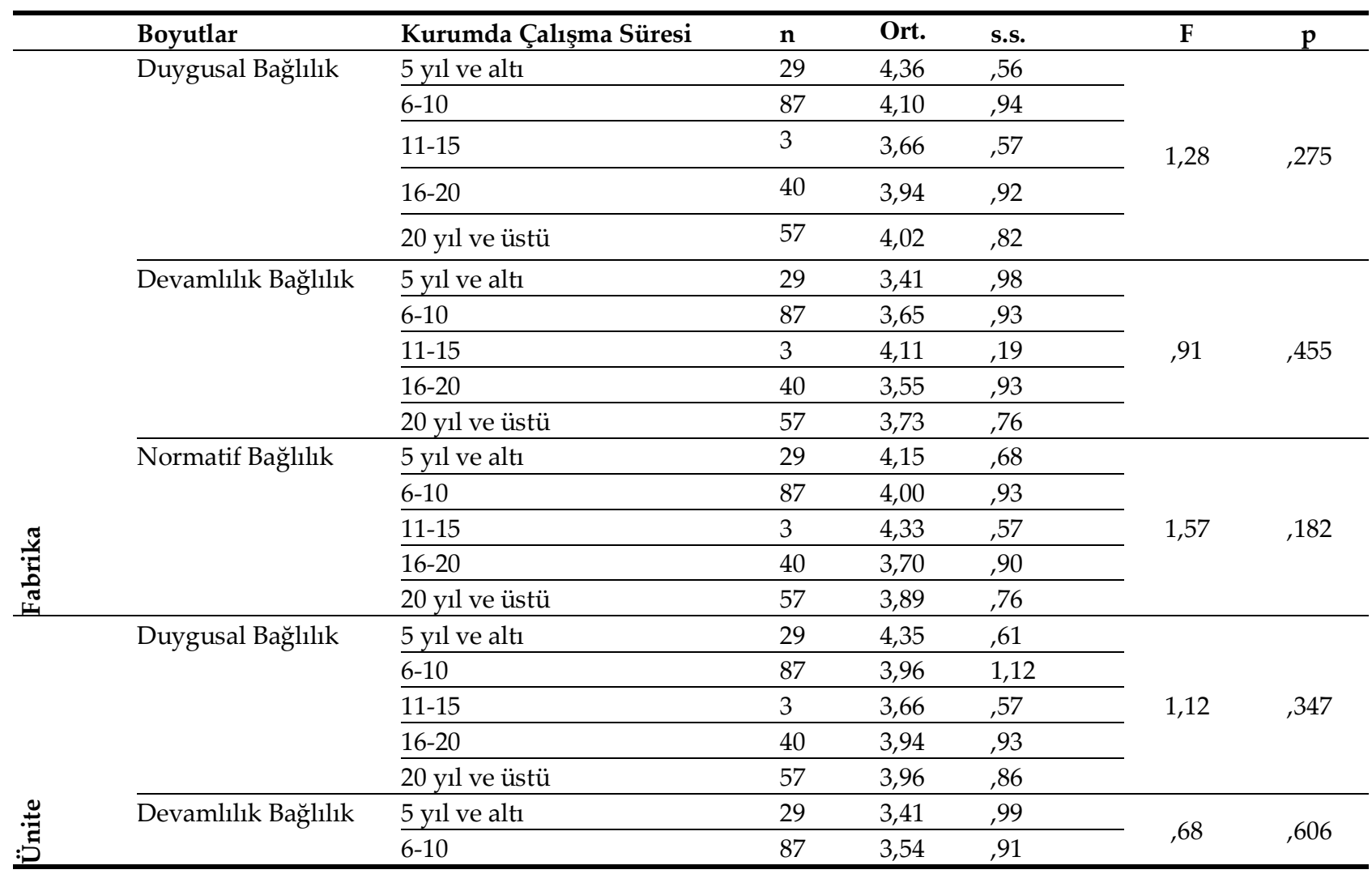


V. Temizkan - K. Y1lmaz 13/2 (2021) 1538-1552

\begin{tabular}{|c|c|c|c|c|c|c|}
\hline & $11-15$ & 3 & 4,11 & , 19 & & \\
\hline & $16-20$ & 40 & 3,52 & ,92 & & \\
\hline & 20 yıl ve üstü & 57 & 3,66 & ,77 & & \\
\hline \multirow[t]{5}{*}{ Normatif Bağlılık } & 5 yil ve üstü & 29 & 4,07 & 68 & \multirow{5}{*}{1,08} & \multirow{5}{*}{,366 } \\
\hline & $6-10$ & 87 & 3,78 & ,97 & & \\
\hline & $11-15$ & 3 & 4,33 & ,57 & & \\
\hline & $16-20$ & 40 & 3,70 & 88 & & \\
\hline & 20 yıl ve üstü & 57 & 3,84 & 80 & & \\
\hline
\end{tabular}

Kurumda çalışma süresi değişkenine göre gerçekleştirilen ANOVA testi sonuçlarında; çalışanların fabrika ve ünite bazında kurumda çalışma süreleri bakımından duygusal, devamlılık ve normatif bağlılık düzeyleri arasında anlamlı $(\mathrm{p}>0,05)$ bir farklılık bulunamamıştır. Bu nedenle $\mathrm{H}_{1.4}$ reddedilmiştir.

Tablo 7. Eğitim Durumu Değişkenine Göre Örgütsel Bağlılık Boyutlarının Farklılaşması (ANOVA Testi)

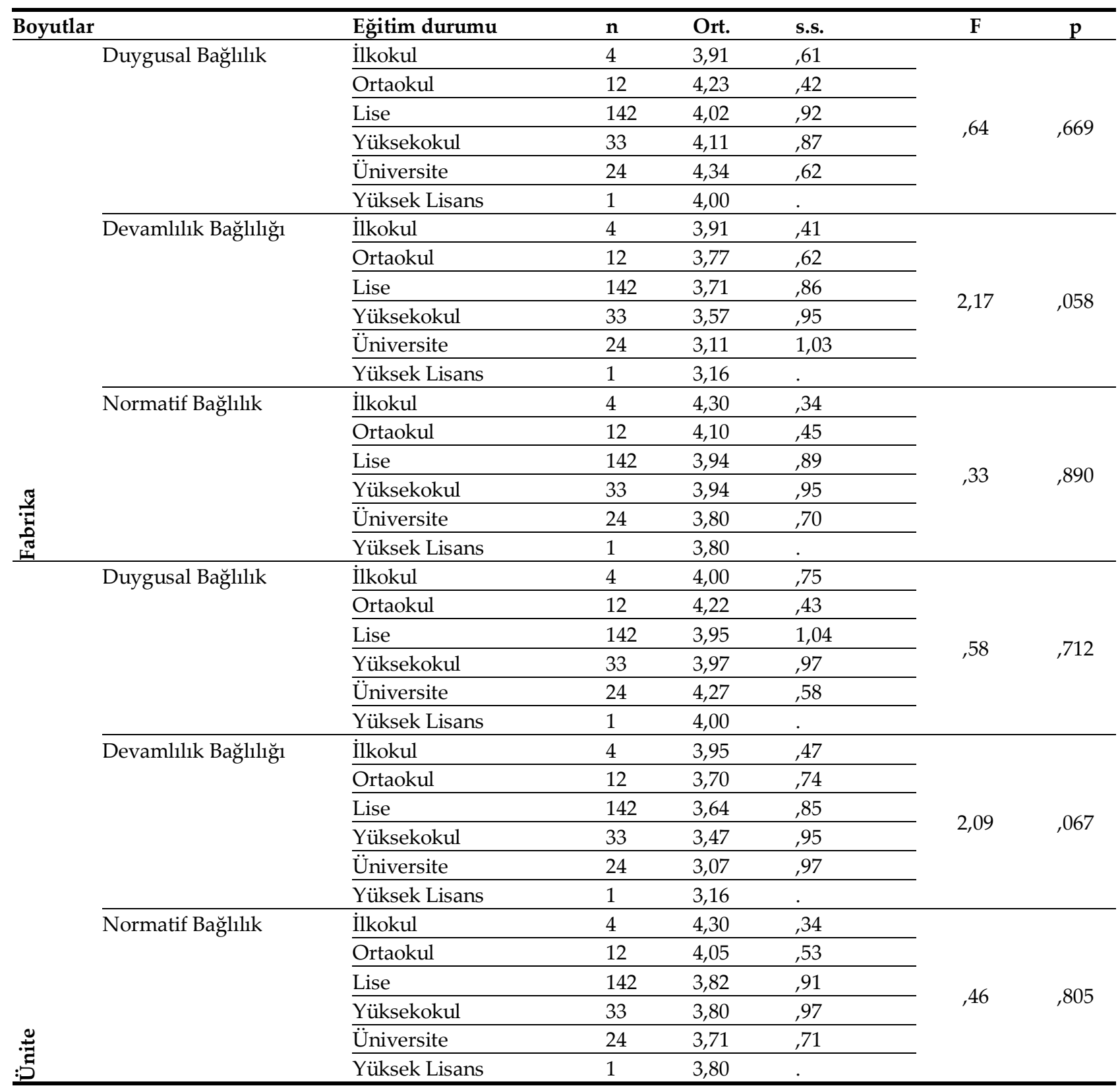

Tablo 7'ye göre çalışanların, fabrikanın geneline ve çalıştıkları üniteye yönelik duygusal, devamlılık ve normatif bağlılık düzeyleri çalışanların eğitim seviyesine göre istatistiksel olarak anlamlı $(p>0,05)$ bir farklılık göstermemektedir. Bu sonuca göre $\mathrm{H}_{1.5}$ hipotezi reddedilmiştir. 
V. Temizkan - K. Y1lmaz 13/2 (2021) 1538-1552

Tablo 8. Yaş Değişkenine Göre Örgütsel Bağlılık Boyutlarının Farklılaşması (ANOVA Testi)

\begin{tabular}{|c|c|c|c|c|c|c|c|}
\hline Boyutlar & & Yaş & $\mathbf{n}$ & Ort. & s.s. & $\mathbf{F}$ & $\mathbf{p}$ \\
\hline \multirow{12}{*}{ 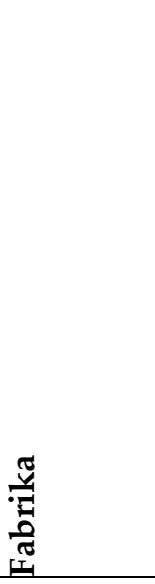 } & \multirow[t]{4}{*}{ Duygusal Bağlılık } & $\underline{21-30}$ & 34 & 4,25 & 82 & \multirow{4}{*}{,- 623} & \multirow{4}{*}{ 601 } \\
\hline & & $31-40$ & 87 & 4,08 & ,93 & & \\
\hline & & $41-50$ & 93 & 4,02 & ,81 & & \\
\hline & & $51-60$ & 2 & 4,16 & 23 & & \\
\hline & \multirow[t]{4}{*}{ Devamlılık Bağlılığı } & $21-30$ & 34 & 3,59 & ,98 & \multirow{4}{*}{-620} & \multirow{4}{*}{603} \\
\hline & & $31-40$ & 87 & 3,55 & 94 & & \\
\hline & & $41-50$ & 93 & 3,71 & 81 & & \\
\hline & & $51-60$ & 2 & 4,00 & ,00 & & \\
\hline & \multirow[t]{4}{*}{ Normatif Bağll1lk } & $21-30$ & 34 & 4,18 & ,72 & \multirow{4}{*}{$-1,836$} & \multirow{4}{*}{142} \\
\hline & & $31-40$ & 87 & 3,99 & 94 & & \\
\hline & & $\underline{41-50}$ & 93 & 3,82 & 81 & & \\
\hline & & $51-60$ & 2 & 3,50 & ,70 & & \\
\hline & \multirow[t]{4}{*}{ Duygusal Bağlllık } & $21-30$ & 34 & 4,23 &, 85 & \multirow{4}{*}{,- 876} & \multirow{4}{*}{, 454} \\
\hline & & $31-40$ & 87 & 3,93 & 1,11 & & \\
\hline & & $\underline{41-50}$ & 93 & 3,98 & 84 & & \\
\hline & & $51-60$ & 2 & 4,33 & 47 & & \\
\hline & \multirow[t]{4}{*}{ Devamlılık Bağlılığı } & $21-30$ & 34 & 3,58 & ,98 & \multirow{4}{*}{,- 879} & \multirow{4}{*}{453} \\
\hline & & $31-40$ & 87 & 3,45 & ,91 & & \\
\hline & & $41-50$ & 93 & 3,65 & ,82 & & \\
\hline & & $51-60$ & 2 & 3,91 &, 11 & & \\
\hline & \multirow[t]{4}{*}{ Normatif Bağlllık } & $21-30$ & 34 & 4,14 & ,71 & \multirow{4}{*}{$-1,76$} & \multirow{4}{*}{, 156 } \\
\hline \multirow{3}{*}{ ص: } & & $31-40$ & 87 & 3,76 & ,97 & & \\
\hline & & $41-50$ & 93 & 3,79 & ,82 & & \\
\hline & & $51-60$ & 2 & 3,50 & ,70 & & \\
\hline
\end{tabular}

Yaş değişkenine göre ANOVA testi sonuçları dikkate alındığında; çalışanların fabrikanın geneline ve çalıştıkları birime yönelik duygusal, devamlılık ve normatif bağlılık düzeyleri, yaş değişkenine göre istatistiksel olarak anlamlı ( $p>0,05)$ bir farklılık göstermemektedir. Bu sonuca göre $\mathrm{H}_{1.6}$ hipotezi reddedilmiştir. Çalışanların çalıştıkları birime ve fabrikanın geneline yönelik örgütsel bağlılık düzeylerinin karşılaştırılmasına ilişkin t-testi sonuçları Tablo 9'da yer almaktadır.

Tablo 9. Üniteye ve Fabrika Geneline Göre Örgütsel Bağlllık Düzeylerinin Farklılaşması (t-Testi)

\begin{tabular}{|c|c|c|c|c|c|c|}
\hline Boyutlar & Değişken & $\bar{n}$ & Ortalama & s.s. & $t$ & $\bar{p}$ \\
\hline \multirow[t]{2}{*}{ Duygusal Bağl1lık } & Fabrika & 216 & 4,08 & 86 & \multirow{2}{*}{1,99} & \multirow{2}{*}{,047 } \\
\hline & Ünite & 216 & 4,01 &, 96 & & \\
\hline \multirow[t]{2}{*}{ Devamlılık Bağl1lığı } & Fabrika & 216 & 3,63 & 89 & \multirow{2}{*}{3,22} & \multirow{2}{*}{,001 } \\
\hline & Ünite & 216 & 3,56 &, 88 & & \\
\hline \multirow[t]{2}{*}{ Normatif Bağllık } & Fabrika & 216 & 3,94 & 85 & \multirow{2}{*}{3,59} & \multirow[b]{2}{*}{,000 } \\
\hline & Ünite & 216 & 3,83 & 87 & & \\
\hline
\end{tabular}

T-testi sonuçlarına göre çalışanların duygusal, devamlılık ve normatif bağlllık düzeyleri fabrika geneli ve çalışılan üniteye göre istatistiksel açıdan anlamlı $(p<0,05)$ bir farklılık göstermektedir. Ortalamalara göre her üç bileşen için de çalışanların fabrika geneline duydukları bağlılık düzeyleri, çalışılan üniteye yönelik duydukları bağlllık düzeylerinden daha yüksektir. Bu sonuca göre $\mathrm{H}_{2}$ hipotezi kabul edilmiştir. Fabrika ve ünite bazında örgütsel bağlılık bileşenleri arasındaki ilişkiye yönelik yapılan korelasyon analizi sonuçları Tablo $10^{\prime}$ da verilmiştir. 
V. Temizkan - K. Yilmaz 13/2 (2021) 1538-1552

Tablo 10. Üniteye ve Fabrikaya Yönelik Bağlllık Düzeyleri Arasındaki Korelasyon Analizi Sonuçları

\begin{tabular}{|c|c|c|c|c|c|c|}
\hline & 1 & 2 & 3 & 4 & 5 & 6 \\
\hline 1-Duygusal Bağlılık (F) & 1 & & & & & \\
\hline 2-Devam Bağlılığ1 (F) & $264^{* *}$ & 1 & & & & \\
\hline 3-Normatif Bağlilık (F) & $710^{* *}$ & $479^{* *}$ & 1 & & & \\
\hline 4-Duygusal Bağlılık (Ü) & $820^{* *}$ &, $251^{* *}$ &, $595^{* *}$ & 1 & & \\
\hline 5-Devam Bağlılığ1 (Ü) & $244^{* *}$ &, $938^{* *}$ &, $442^{* *}$ &, $288^{* *}$ & 1 & \\
\hline 6-Normatif Bağl1lık (Ü) & $632^{* *}$ & $408^{* *}$ &, $861^{* *}$ & $651^{* *}$ & $475^{* *}$ & 1 \\
\hline${ }^{* *} \mathrm{p}<0,01 ;{ }^{*} \mathrm{p}<0,05$ & & & & & & \\
\hline
\end{tabular}

Tablo 10'daki korelasyon sonuçlarına göre; çalışanlar fabrikaya ve çalıştıkları üniteye yönelik her üç değişken bazında da pozitif, anlamlı ve yüksek düzeyde ilişki göstermektedir. Bu sonuca göre $\mathrm{H}_{3}$ hipotezi kabul edilmiştir. Üniteye ve fabrika geneline yönelik duygusal $(0,820)$, devamlılık $(0,938)$ ve normatif $(0,861)$ bağlll $1 \mathrm{k}$ düzeyleri arasındaki korelasyonların yüksek olması, üniteye yönelik yüksek bağlllık düzeyine sahip olan çalışanın fabrika geneline yönelik olarak da yüksek seviyede bağlllık düzeyine sahip olduğunu göstermektedir. Aynı şekilde, fabrika geneline duyulan bağlılık düzeyi arttığında çalışılan üniteye yönelik bağl1lık düzeyinin de artacağı öngörülebilir.

\section{TARTIŞMA VE SONUÇ}

İşletme çalışanlarının hem ünite hem de işletme bazında örgütsel bağlllık düzeylerinin demografik özelliklere göre anlamlı düzeyde farklılık gösterip göstermedikleri t-testiyle incelenmiştir. T-testi sonuçlarına göre cinsiyet, çalışma süresi, eğitim ve yaş değişkenleri açısından demografik özelliklere göre çalışanların örgütsel bağlılık düzeyleri arasında anlamlı bir farklılık belirlenmemiştir. Ancak fabrika geneli düzeyinde çalışılan pozisyon değişkenine göre devamlılık bağlılı̆̆ bileşeninde, medeni durum değişkenine göre ise normatif bağlllık bileşeninde anlamlı bir farklılık saptanmıştır. Hem ünite hem de fabrika geneli düzeyinde diğer tüm bileşenlerde t-testi sonuçları anlamsız $(\mathrm{p}>0,05)$ olduğundan $\mathrm{H}_{1}$ hipotezi tüm alt hipotezlerle birlikte reddedilmiştir. Diğer bir deyişle çalışanların örgütsel bağlllık düzeyleri ve türleri demografik özelliklere göre anlamlı bir farklılık göstermemektedir. Bu sonuç yapılan bazı araştırmaların sonuçlarıyla örtüşmektedir (Yalçın \& İplik, 2005;409) ancak aşağıda verilen bazı araştırma sonuçlarına göre farklılık göstermektedir.

Demografik özelliklerin çalışanların örgütsel bağlllıklarına etki ettiğini ortaya koyan çalışmalar da mevcuttur. $\mathrm{Bu}$ araştırmalarda farklı sonuçların çıkmasının önemli nedenlerinden birisi araştırmaya konu çalışanların sahip oldukları kültürel özelliklerdir. Mesela Ortadoğu'da insanlar genelde çalıştıkları yere duygusal ve normatif bir bağlılık geliştirmektedirler (Özkaya, Kocakoç \& Karaa, 2006;92). Yine Çolakoğlu, Ayyıldız, \& Cengiz (2009;86) tarafından yapılan çalışmada eğitim durumu, gelir ve çalışılan departman değişkenlerine göre otel çalışanlarının örgütsel bağlllık algılarının değiştiği belirlenmiştir. Suudi Arabistan'da kamu kuruluşlarında yapılan bir araştırmada yaş ve eğitim değişkenlerinin örgütsel bağllık düzeyleriyle ilişkili oldukları tespit edilmiştir (Al-Kahtani, 2012;7). Gana'da banka çalışanları arasında yapılan bir çalışmada cinsiyet, yaş, eğitim, tecrübe ve medeni durum değişkenleriyle örgütsel bağlllık düzey ve niteliğinin ilişkili olduğu sonucuna varılmıştır (Affum-Osei, Acquaah, \& Acheampong, 2015;775).

Fabrika geneline yönelik normatif bağlllık düzeyleri çalışanların medeni durumlarına göre anlamlı $(\mathrm{p}<0.05)$ bir farklılık göstermektedir. Aynı şekilde hem fabrika geneli hem de ünite bazında devam bağlılığı düzeyleri çalışılan pozisyon değişkenine göre anlamlı $(\mathrm{p}<0.05)$ bir farklılık göstermektedir. Bu farklılığın, işçilerin işletmeden ayrılmaları durumunda daha yüksek bir maliyete katlanacakları fikrine sahip olmalarından kaynaklandığı düşünülmektedir. İşçiler kendilerinin yöneticilere göre örgütten ayrılmaları halinde daha zor iş bulabileceklerini düşünmektedirler. Dolayısıyla örgütten ayrılmaları halinde katlanacakları maliyet ve karşılaşacakları güçlükler daha fazla olacaktır. Karabük ilinin istihdam potansiyelinin düşük olması da çalışanların örgüte yönelik devamlılık bağlılığını arttırııı bir role sahiptir.

Araştırmada beyaz yakalı çalışanların devam bağllı̆̆ı diğer pozisyonlara göre daha düşük çıkmıştır. Beyaz yakalıların iyi eğitimli ve kalifiye olmaları başka şehirlerde benzer şartlarda iş bulabileceklerini göstermektedir. Ancak işletmenin kendi sektöründe büyük bir marka olmasının, beyaz yakalı çalışanlarında yüksek düzeyde duygusal bağlılığa yol açtığını söyleyebiliriz. Berthon vd. (2005;156)'e göre, çalıştığı kurumu "çalışılacak en iyi iş yeri" olarak gören çalışanların örgüte olan bağlllıklarının artması işletmelerde güçlü "işveren markalarının" yarattı̆̆ bir sonuçtur. 


\section{Temizkan - K. Y1lmaz 13/2 (2021) 1538-1552}

Ünite ve fabrika geneli bazında çalışanların örgütsel bağllık düzeylerinin karşılaştırılmasına ilişkin t-testi sonuçlarına göre, örgütsel bağlılık bileşenleri olan duygusal, devamlılık ve normatif bağlllık düzeyleri çalışılan ünite ve fabrika geneli değişkenlerine göre anlamlı bir farklılık göstermektedir. Ortalamalar göstermektedir ki çalışanlarda en fazla duygusal bağlılık gelişmiştir. Sonra sırasıyla normatif ve devamlılık bağlılığı gelmektedir. Bu durum işletme açısından arzulanan bir sonuçtur. Ayrıca her üç bileşende fabrika geneli bağlılık düzeylerinin çalışılan ünite bazlı bağlılık düzeyinden fazla olduğu gözlenmiştir. Bu sonuçlara göre çalışanları örgütsel bağlılık açısından motive eden unsurlar çalışılan ünitelerden ziyade işletme genelinden kaynaklanan özelliklerdir. Bu özellikler arasında işletmenin sektördeki öncülügüu, büyüklügü̈, imajı, kurumsallığı gibi özellikleri yanında çalışanına sağladığı sosyal ve ekonomik haklar ve imkanlar sayılabilir.

İşletmede bulunmaktan dolayı duyulan memnuniyet ve tatmin, örgütsel bağl1lı̆̆1 doğuran etmenlerdir. Araştırma neticesinde işletme genelinde duygusal bağlılık ortalamalarının yüksek çıktığı, devamlılık bağlılığının ise son sırada yer aldığı görülmüştür. Aynı sıralama ünite bazında örgütsel bağlılık ortalamaları için de geçerlidir. Duygusal bağlllı̆̆ etkileyen unsurlar arasında yönetimin adil olması ve iş tatmini (Powell ve Meyer, 2004;168); (Vandenberghe ve Peiro, 1999;579); (İplik vd., 2012;112), iş çevresindeki fiziki ve psikolojik şartlar (Tolentino, 2013;54-55), işbirliğine dayalı liderlik ve eşit düzeyde destek uygulamaları ((Joo, 2010;80) sayılabilir. Bunun yanında duygusal bağlılık, iş performansı, örgütsel aidiyet ve müşteriye yönelik çalışan yaklaşımlarını olumlu olarak etkiler (Allen ve Grisaffe, 2001;219). Örgütler açısından devamlılık bağ llılı̆̆ tercih edilmeyen bir durumdur ve çalışanda zoraki bir bağlllığa işaret eder. Bu açıdan bu araştırmanın yapıldığı işyeri örgütsel bağlılığı sağlayıcı tedbir ve uygulamalar konusunda oldukça başarılıdır denilebilir. Çünkü iş tatmini, performans ve memnuniyet, örgütsel bağlllıkla ilişkilidir. Bu işletmede çalışanların işletmelerinin değer ve hedeflerini benimsedikleri, örgütte kalma niyetlerinin işlerini ve işletmelerini sevmelerinden kaynaklandığı anlaşılmaktadır. Bu sonuç işyeri açısından da tercih edilen bir sonuçtur.

Korelasyon analizi sonuçlarına göre çalışanların hem fabrikaya hem de çalıştıkları üniteye yönelik her üç bağlılık bileşeninin düzeyleri arasında anlamlı, pozitif ve yüksek derecede ilişki bulunmuştur. Bulunan bu sonuç, ileri sürülen "Fabrika ve ünite bazında örgütsel bağlllık bileşenleri arasında anlamlı bir ilişki vardır" hipotezini doğrulamaktadır. Her üç örgütsel bağlllık bileşeni için de üniteye yönelik bağlllık düzeyinin artmasıyla fabrika geneline yönelik bağlılık düzeyinin de artacağı söylenebilir. Korelasyon analizinin niteliği gereği bu öngörünün tersi de doğrudur. Bu analizde en yüksek ilişki düzeyi devamlılık bağlllı̆̆ı bileşeninin ünite ve fabrika geneli değişkenleri arasında görülmüştür $(0,938)$. Ünite ve fabrika geneli örgütsel bağlllık düzeyleri arasında yüksek düzeyde korelasyon bulunması literatür sonuçlarıyla uyumludur. Conway ve Briner'a göre, kollektif örgütsel bağlllık ünite seviyesinde meydana gelen paylaşımlarla başlar ve oluşur, çünkü ünitelerde paylaşımlar daha yoğundur (Conway ve Briner, 2012;472). Takım halinde geliştirilen örgütsel bağlılık hem takım performansını arttırmakta hem de bireysel fedakarlık davranışını arttırmaktadır (Neininger vd., 2010;573).

$\mathrm{Bu}$ çalışma hem işletme geneli hem de çalışllan ünite göz önünde bulundurularak çalışanların örgütsel bağllı̆̆ı̆ını arttıracak motivasyon unsurlarına eğilmenin önemini ortaya koymaktadır. Hangi seviyede olursa olsun bu motivasyon unsurları genel bağlllık seviyesine etkide bulunacaktır.

Bu çalışmanın sınırlılığı, araştırmanın tek bir fabrikada gerçekleştirilmiş olmasıdır. Benzer çalışmaların farklı sektörlerde gerçekleştirilecek mukayesesi literatüre önemli katkılar sağlayacaktır.

Aynı işletmenin farklı fonksiyonları yerine getiren ünitelerinde çalışanların kendi birimlerinden kaynaklanan iş tatmini, performans, memnuniyet ve örgütsel bağlllık özelliklerinin, örgüt geneline göre farklılık gösterip göstermediğine ilişkin çalışmaların artmasının faydalı olacağı değerlendirilmektedir. 


\section{Temizkan - K. Y1lmaz 13/2 (2021) 1538-1552}

\section{KAYNAKÇA}

Affum-Osei, E., Acquaah, E., \& Acheampong, P. (2015). Relationship between organisational commitment and demographic variables: Evidence from a commercial bank in Ghana. American Journal of Industrial and Business Management, 5(12), 769.

Al-Kahtani, S. N. (2012). An exploratory study of organizational commitment, demographic variables and job \& work related variables among employees in Kingdom of Saudi Arabia, Online International Interdisciplinary Research Journal, 3, 1-13.

Allen, N., J. ve Meyer, J., P. (1990). The measurement and antecedents of affective, continuance, and normative commitment to the organization, Journal of Occupational Psychology, 63 (1): 1-18.

Allen, N. J., ve Grisaffe, D. B. (2001). Employee commitment to the organization and customer reactions: mapping the linkages, Human Resource Management Review, 11(3), 209-236.

Aydın, M. B. (2018). Karabük'te fabrika'nın kuruluşu ve ilk işçiler: 1940'lı yıllarda çeltik tarlasından sanayi kentine dönüşüm, Akademik Sosyal Araştırmalar Dergisi, 6(65), 270-271.

Bağcl, Z. (2013). Çalışanların örgütsel adalet algılarının örgütsel bağlllıkları üzerindeki etkisi: Tekstil sektöründe bir inceleme, Uluslararası Yönetim İktisat ve İşletme Dergisi, 9(19), 163-184.

Berthon, P.,Ewing, M. ve Hah, L. L. (2005). Captivating company: Dimensions of attractiveness in employer branding. International Journal of Advertising, 24 (2), 151-172

Boylu, Y., Pelit E. ve Güçer, E., (2007). Akademisyenlerin örgütsel bağlllık düzeyleri üzerine bir araştırma, Finans Politik \& Ekonomik Yorumlar, S.511 s.55-74.

Conway, N. ve Briner, R. B. (2012). Investigating the effect of collective organizational commitment on unit level performance and absence, Journal of Occupational and Organizational Psychology, 85(3), 472-486.

Conway, N., ve Briner, R. B. (2015). Unit-level linkages between employee commitment to the organization, customer service delivery and customer satisfaction, The International Journal of Human Resource Management, 26(16), 2039-2061.

Çehreli, A. (1966). Türkiye demir ve çelik işletmelerinde işçi-işveren münasebetleri, Sosyal Siyaset Konferansları Dergisi, (17), 137-150.

Çolakoğlu, Ü., Ayyildiz, T., \& Cengiz, S. (2009). Çalışanların demografik özelliklerine göre örgütsel bağlllık boyutlarında algılama farklılıkları: Kuşadası'ndaki beş yıldızlı konaklama işletmeleri örneği, Anatolia: Turizm Araştırmaları Dergisi, 20(1), 77-89.

Dağll, A., Elçiçek, Z., \& Han, B. (2018). Örgütsel bağlllık ölçeği'nin Türkçeye uyarlanması: Geçerlik ve güvenirlik çalışması, Electronic Journal of Social Sciences, 17(68).

Eaton, S. C. (2003). If you can use them: Flexibility policies, organizational commitment, and perceived performance. Industrial Relations, 42, 145-167

Eslami, J. ve Gharakhan, D. (2012). Organizational commitment and job satisfaction, ARPN Journal of Science and Technology, 2 (2).

Fındık, M., \& Eryeşil, K., (2012). Örgütsel sinizmin örgütsel bağl1lık üzerindeki etkisini belirlemeye yönelik bir araştırma, International Iron \& Steel Symposium, 02-04 April 2012, Karabük, Türkiye.

Furaker, B. ve Berglund, T. (2014). Job insecurity and organizational commitment, RIO: Revista Internacional de Organizaciones, (13), 163-186.

Gegez, E. (2010). Pazarlama araştırmaları. 3. Bask1. İstanbul: Beta.

Graham, J. W., Cumsille, P. E., \& Shevock, A. E. (2012). Methods for handling missing data. Handbook of Psychology, Second Edition, 2. 


\section{Temizkan - K. Yilmaz 13/2 (2021) 1538-1552}

İplik, E., İplik, F. N., \& Efeoğlu, İ. E. (2012). İşgörenlerin örgütsel sosyalizasyon düzeylerinin iş tutumları üzerindeki etkisinin belirlenmesine yönelik bir araştırma, Çă̆ Üniversitesi Sosyal Bilimler Dergisi, 9(2), 100-115.

İSO (2019) Türkiye'nin 500 büyük sanayi kuruluşu, http://www.iso500.org.tr/500-buyuk-sanayikurulusu/2019/, (Erişim Tarihi: 3 Haziran 2020).

Joo, B. K. (2010). Organizational commitment for knowledge workers: The roles of perceived organizational learning culture, leader-member exchange quality, and turnover intention, Human Resource Development Quarterly, 21(1), 69-85.

Karabük Demir Çelik ve Sanayi A.Ş. (2019). Kilometre taşları, https://www.kardemir.com/kilometre_taslari, (Erişim Tarihi: 10 Haziran 2020).

Malhotra, N.K. (2010). Marketing research: An applied orientation, 6. Bask1. London: Pearson Education.

MacCallum, R.C., K.F. Widaman, S. Zhang ve S. Hong (1999). Sample size in factor analysis, Psychological Methods, 4 (1), 84-99.

Mathur, U. C. (2008). International marketing management: Text and cases. SAGE Publications India Pvt Ltd.

Meyer, J. P., Bobocel, D. R., \& Allen, N. J. (1991). Development of organizational commitment during the first year of employment: A longitudinal study of pre-and post-entry influences. Journal of management, 17(4), 717-733.

Mowday, R. T., Porter, L. W. ve Steers, R. M. (2013). Employee-organization linkages: The psychology of commitment, absenteeism, and turnover, Academic press.

Neininger, A., Lehmann-Willenbrock, N., Kauffeld, S. ve Henschel, A. (2010). Effects of team and organizational commitment-A longitudinal study, Journal of Vocational Behavior, 76(3), 567-579.

Özkaya, M. O., Kocakoç, İ. D., \& Karaa, E. (2006). Yöneticilerin örgütsel bağlılıkları ve demografik özellikleri arasındaki ilişkileri incelemeye yönelik bir alan çalışması, Yönetim ve Ekonomi: Celal Bayar Üniversitesi İktisadi ve İdari Bilimler Fakültesi Dergisi, 13(2), 77-96.

Powell, D. M. ve Meyer, J. P. (2004). Side-bet theory and the three-component model of organizational commitment, Journal of Vocational Behavior, 65, 157-177.

Sayğan, F., N. (2011). Relationship between affective commitment and organizational silence: A conceptual discussion, International Journal of Social Sciences And Humanity Studies, 3 (2).

Tabachnick, B. G., Fidell, L. S., (2013). Fidell using multivariate statistics (sixth ed.), Boston, MA: Pearson.

Tavakol, M., \& Dennick, R. (2011). Making sense of cronbach's alpha, International journal of medical education, 2: 53-55.

Tolentino, R. C. (2013). Organizational commitment and job performance of the academic and administrative personnel, International Journal of Information Technology and Business Management, 15(1), 51-59.

Vandenberghe, C. ve Peiro', J. M. (1999). Organizational and individual values: Their main and combined effects on work attitudes and perceptions, European Journal of Work and Organizational Psychology, 8, 569-581.

Yalçın, A., \& İplik, N. F. (2005). Beş yıldızlı otellerde çalışanların demografik özellikleri ile örgütsel bağlılıkları arasındaki ilişkiyi belirlemeye yönelik bir araştırma: Adana ili örneği, Çukurova Üniversitesi Sosyal Bilimler Enstitüsü Dergisi, 14(1), 395-412.

Yaşin B. (2014). Pazarlama araştırmaları, İstanbul Üniversitesi açık ve uzaktan eğitim fakültesi ortak ders kitabı, http://auzefkitap.istanbul.edu.tr/kitap/kok/pazarlamaarastirmalari.pdf, (Erişim tarihi: 07 Hazirab 2021).

Yücel, İ. ve Çetinkaya, B. (2015). Örgütsel sinizm ile örgütsel bağlllık arasındaki ilişki ve çalışanların yaşının bu ilişki üzerindeki etkisi-“bazen hoşlanmasak da kalmak zorunda olabiliriz!". Atatürk Üniversitesi Sosyal Bilimler Enstitüsü Dergisi, 19(3). 